\title{
25. HATTON DRIFT CONTOURITES, NORTHEAST ATLANTIC, DEEP SEA DRILLING PROJECT LEG 81 ${ }^{1}$
}

\author{
Dorrik A. V. Stow and Julian A. Holbrook, University of Edinburgh ${ }^{2}$
}

\begin{abstract}
The mid-Miocene to Recent sediments cored at the four Northeast Atlantic sites on DSDP Leg 81 were deposited under the influence of a persistent bottom-current system. Minor hiatuses and condensed sequences indicate stronger bottom-current activity. Most of the sediments are sandy mud to muddy sand grade, biogenic contourites that differ only slightly from normal pelagic and hemipelagic deposits. An impersistent and often subtle lamination is the most obvious characteristic indicating current-influenced sedimentation.
\end{abstract}

\section{INTRODUCTION}

The four sites drilled on the western margin of the Rockall Plateau during Leg 81 (Fig. 1) penetrated up to $650 \mathrm{~m}$ of Paleogene to Recent sediments overlying volcanic basement. They are situated at the extreme southern end of a large elongate sediment drift known as the Hatton Drift (Ruddiman, 1972), in a present-day water depth of $1600-2500 \mathrm{~m}$. The morphological expression of the drift is slight in this area, but differential sediment thicknesses indicate that there has been some current control on deposition, with greater accumulation along the foot of the Rockall Plateau since early Miocene time (Roberts and Montadert, 1979). Seismic profiles across the Hatton Drift (Ruddiman, 1972; Ewing et al., 1974) show weak parallel internal reflectors in the upper $200 \mathrm{~m}$ of section and an irregularly undulating surface.

Present-day hydrographic data in the vicinity of the Gardar and Hatton drifts has been summarized by McCave et al. (1980). These authors document a strong northeast flowing bottom current along the foot of the Hatton Drift, made up of North Atlantic Deep Water with some admixture of Antarctic Bottom Water (Fig. 1). Measured current velocities reach a maximum of 23 $\mathrm{cm} / \mathrm{s}$ and appear to be moving winnowed foraminiferal sands into ripples and low-amplitude waves. The bottom mixed-water layer and nepheloid suspension is up to $100 \mathrm{~m}$ thick. Higher up on the drift, current velocities are lower, the nepheloid layer thinner, and finer grained sediments are deposited, perhaps from current eddies dissipating their energy in the relatively more slack water over the drift.

Two previous DSDP Sites (Sites 403 and 404) and one Lamont piston core provided the only data on Hatton Drift sediments prior to Leg 81 , although no very detailed descriptions exist. The sediments appear to be mainly calcareous, biogenic, bioturbated, and finegrained with some winnowed foraminiferal sands. Our

\footnotetext{
${ }^{1}$ Roberts, D. G., Schnitker, D., et al., Init. Repts. DSDP, 81: Washington (U.S. Govt. Printing Office).

2 Address: Grant Institute of Geology, University of Edinburgh, West Mains Road, Edinburgh EH9 $3 \mathrm{JW}$, United Kingdom
}

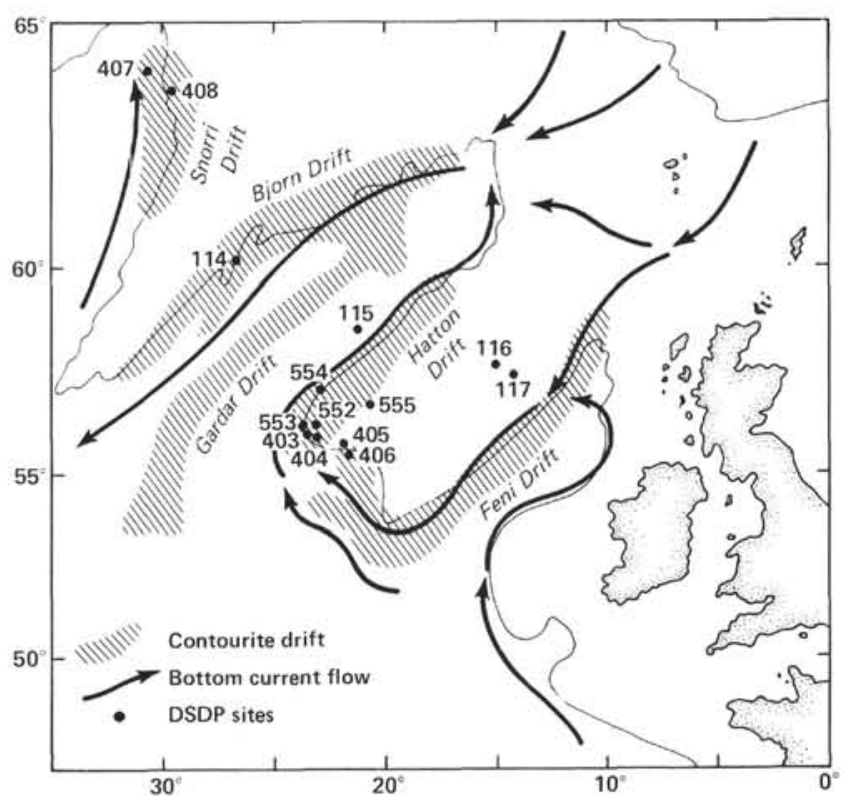

Figure 1. Map of Northeast Atlantic showing location of DSDP Leg 81 and adjacent sites, major sediment drifts, and present-day bottom circulation.

aim in this short chapter is to document the sedimentological characteristics of the Hatton Drift contourites drilled on Leg 81 .

\section{HIATUSES AND BOTTOM CIRCULATION}

Late Paleocene-Recent sedimentation at the Leg 81 and adjacent sites shows four distinct phases (Fig. 2):

1. Late Paleocene to early Eocene: rapid accumulation $(10$ to $>50 \mathrm{~m} / \mathrm{m}$.y.) of terrigenous and volcaniclastic sediments in relatively shallow water.

2. Early Eocene-early Miocene: nondeposition and patchy accumulation of reduced sections (average rate of accumulation $<1 \mathrm{~m} / \mathrm{m} . \mathrm{y}$.), concentrations of manganese encrustations and glauconite in deeper water.

3. Mid-Miocene-late Pliocene: more or less continuous biogenic sedimentation with local minor hiatuses, at variable rates of accumulation (6 to $27 \mathrm{~m} / \mathrm{m}$.y.) in near present oceanic depths. 


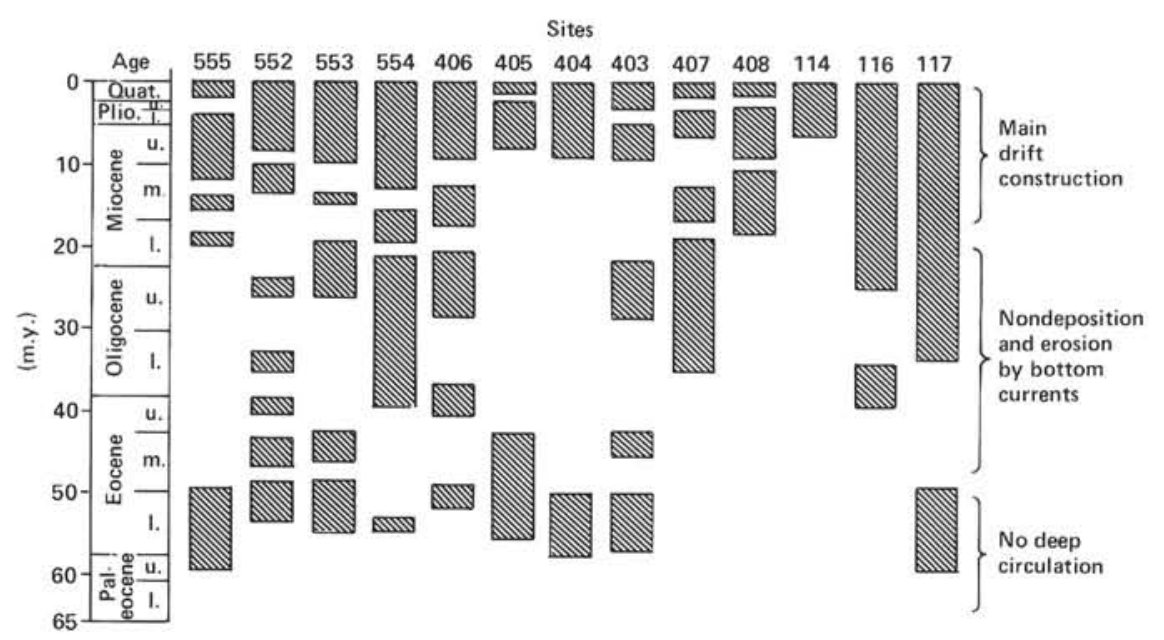

Figure 2. General stratigraphy and hiatuses of DSDP Leg 81 and adjacent sites.

4. Late Pliocene-Recent: continuous sedimentation with more and less biogenic-rich cycles, glacial dropstones, and slightly higher rates of accumulation (13 to $40 \mathrm{~m} / \mathrm{m} . \mathrm{y}$.).

The widespread nondepositional event through much of the Eocene and Oligocene has been related to global changes in bottom water circulation. This was probably linked to pronounced Antarctic cooling and to the development of strong Antarctic Bottom Water flow throughout the Atlantic and perhaps also to the formation of cold Labrador Sea Water (Shor and Poore, 1979; Schnitker, 1980; Stow, 1982). Major construction of the Hatton Drift, as well as most of the other Northeast Atlantic drifts, appears to have begun sometime in the early to mid-Miocene. Three important circulation events in the Miocene that may have influenced this drift construction are: the overflow of Norwegian Sea Water, the inflow of Mediterranean Sea Water into the Atlantic, and the intensification of the Gulf Stream.

Minor hiatuses in the sedimentation (Fig. 2) are found between the early and middle Miocene (Sites 554, 555, and 406), within the middle Miocene (Sites 552, 553, 555, and 406), within the late Miocene (Sites 554, 403, and 405), and in the Pliocene (Sites 554 and 555). These are probably related to variations in intensity and location of the bottom currents during drift formation. No hiatuses were recorded within the Pleistocene sections.

\section{SEDIMENT CHARACTERISTICS}

The mid-Miocene to Recent sediments that make up the Hatton Drift accumulation at each of the Leg 81 sites are assumed to have been deposited under the variable influence of bottom currents during the Neogene. These sediments can therefore be considered typical of mid-ocean drift contourites (Davies and Laughton, 1972; Stow and Lovell, 1979). Their chief structural, textural, and compositional attributes will be described in two parts: (1) those deposited prior to the onset of northern hemisphere glaciation, and (2) those deposited during the glacial-interglacial cycles.

\section{Mid-Miocene-Late Pliocene Contourites}

The main lithology of this age at each site is a bluishwhite or whitish biogenic ooze (becoming chalk below about $100 \mathrm{~m}$ ) forming lithologic Unit II (see site chapters, this volume). This varies in thickness from $77.5 \mathrm{~m}$ at Site 554, the most westward of the sites, to $230 \mathrm{~m}$ at Site 555, which is situated between Hatton and Edoras banks near to the present-day axis of the North Atlantic Drift current.

Where not affected by coring disturbances, the sediments range from completely homogeneous, apart from indistinct bioturbational mottling and rare burrows, to well laminated (Fig. 3). The laminae are mostly between 1 and $10 \mathrm{~mm}$ thick with gradational contacts and, although grossly parallel, are commonly wavy to irregular in shape. They are picked out by a color banding with barely any compositional or textural distinction between adjacent laminae. Minor bioturbation and burrowing is present throughout but has been insufficient to destroy the primary lamination. In Hole 552A, there is a welllaminated section between Cores 17 and 24 (about $35 \mathrm{~m}$ thick) in which the laminae are steeply inclined (20$80^{\circ}$ ), with small-scale overfolds and microfaults. This interval has probably been displaced from higher on the drift or bank by slumping.

Texturally, the sediments are mainly silty muds and sandy muds, more rarely fine silty clay or muddy sand grades. Conventional sieve and pipette grain size analyses (Fig. 4) on these biogenic sediments show a range from those with a more-or-less even distribution of size fractions between about 1 and $250 \mu \mathrm{m}$ ( 10 phi to 2 phi) to those with a more distinct fine silt to clay mode (1-10 $\mu \mathrm{m}, 10-7 \mathrm{phi})$ and a smaller coarse tail. The shapes of the cumulative frequency grain size curves are thus from logarithmic to hyperbolic-logarithmic in the terminology of Rivière (1977).

The sediment composition is almost entirely biogenic, comprising dominantly foraminifers and nannofossils in varying proportions, up to $10 \%$ siliceous biogenics (sponge spicules, radiolarians, and diatoms), and mi- 

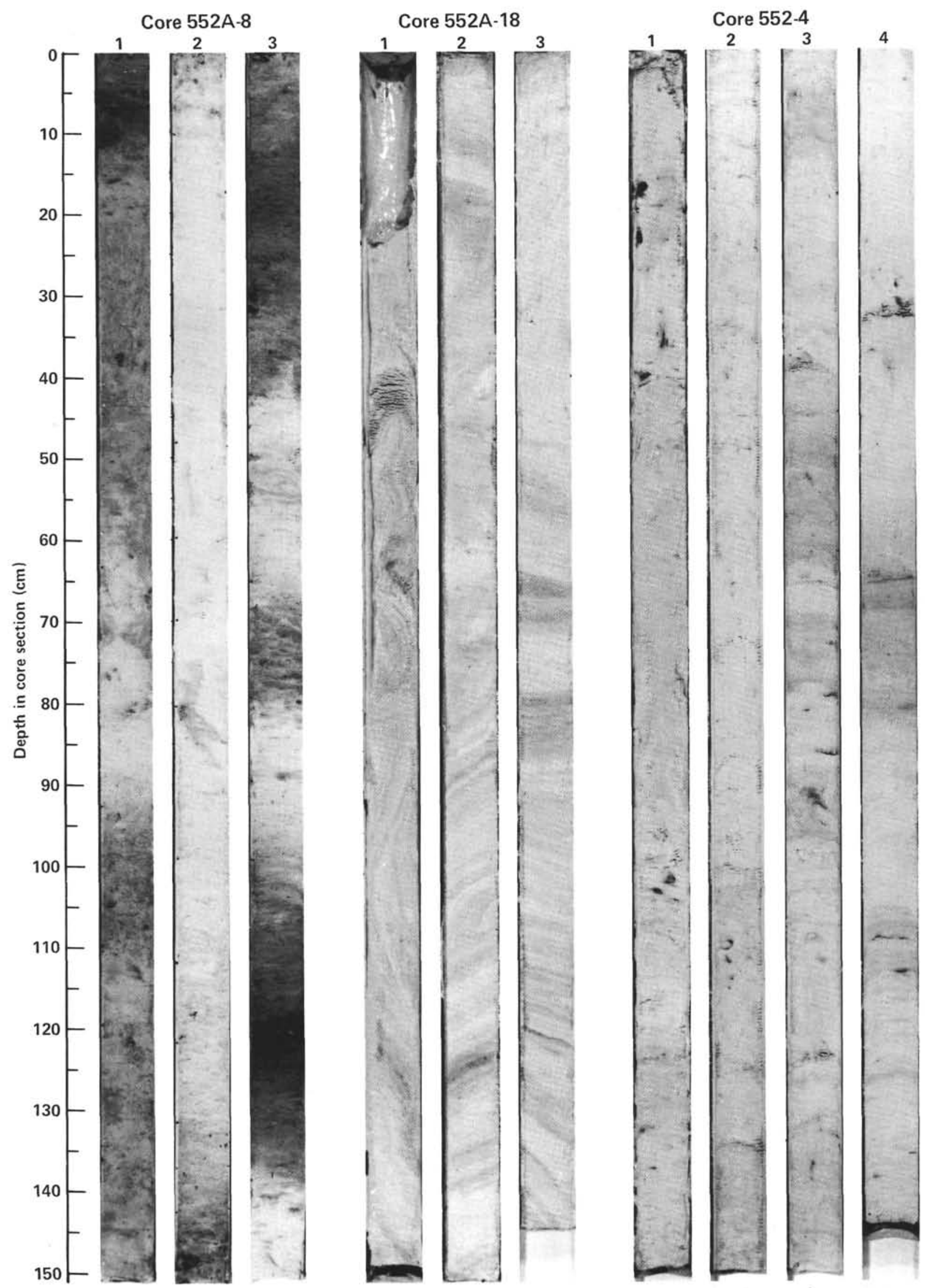

Figure 3. Typical contourite facies in Hatton Drift cores. 


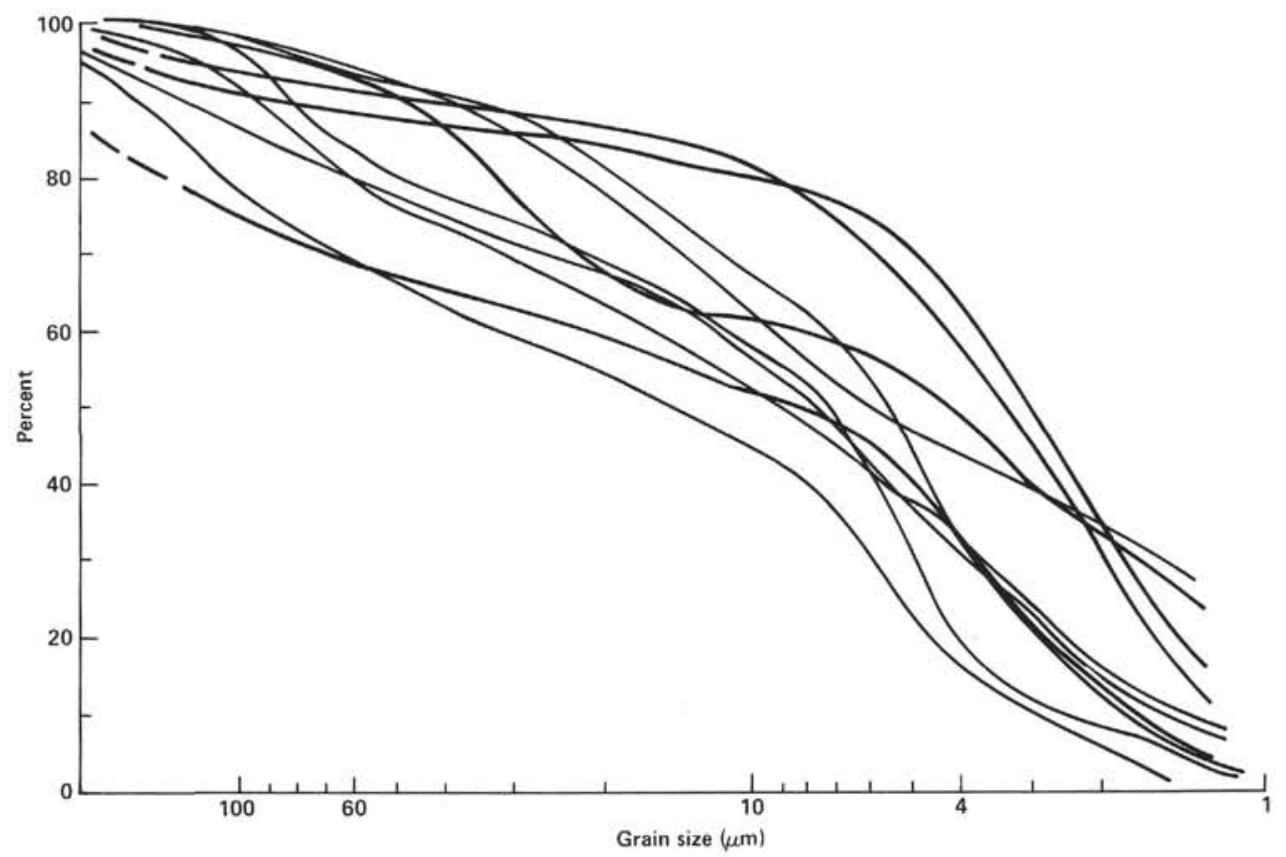

Figure 4. Cumulative frequency grain-size distribution curves for selected Hatton Drift contourites.

nor benthic foraminifers, ostracods, echinoid spines, and fish debris. The carbonate percentage varies slightly around $90 \%$; there is a small terrigenous component (smectite, detrital quartz, volcanogenics), and some authigenic iron sulfide commonly associated with burrows. There may be rare glacial dropstones in the upper few meters, and a marked increase of probable deep-water authigenic glauconite $(1-20 \%)$ associated with reduced carbonate sedimentation, more siliceous biogenics, and minor or major hiatuses in the lowest few meters of Unit II (Morton, this volume).

\section{Late Pliocene-Recent Contourites}

The late Pliocene to Recent section, forming Unit I at the Leg 81 sites, is between $21.5 \mathrm{~m}$ (Site 555) and $50 \mathrm{~m}$ (Site 553) thick. It is made up of alternating cycles of pale yellow brown to whitish biogenic oozes and brownish or grayish marls/calcareous muds (Fig. 3). Individual beds vary in thickness from less than $20 \mathrm{~cm}$ to over $100 \mathrm{~cm}$ and there may be as many as 40 separate cycles or couplets (see site chapters, this volume). The detailed description of this sequence and interpretation of the cycles in terms of climatic changes through the glacialinterglacial episodes of the past $2.4 \mathrm{~m}$.y. is the subject of several other papers in this volume (e.g., Zimmerman; Shackleton and Hall; Schnitker; Huddlestun). We simply outline the chief sedimentological attributes, particularly emphasizing how they differ from those of the Mio-Pliocene sediments.

Apart from the interstratified light- and dark-colored beds with relatively sharp or gradational contacts, there is little other primary sedimentary structure. There are only rare laminae and thin $(1-5 \mathrm{~cm})$ beds of ooze, marl, or mud, and these are commonly irregular or indistinct. Bioturbation and burrowing is ubiquitous, being particularly evident at the contacts between beds.
The textures of the oozes are very similar to those of the underlying sequence (Fig. 4), namely sandy muds or muddy sands with a relatively even (logarithmic) distribution of grain sizes or a small coarse tail (hyperbolic). The interbedded marls and muds are also similar, but tend to show a more irregular distribution, with isolated cobbles, pebbles, granules, and sand-size grains that most likely result from ice rafting.

Compositionally, the oozes are dominantly foraminiferal-nannofossil oozes (80-90\% carbonate) with only rare siliceous and other calcareous biogenic material, and traces of smectite, quartz, and volcanic ash. At the other extreme, some of the muds have as little as $5 \%$ carbonate, a range of clays (illite, kaolinite, chlorite, and smectite), quartz, feldspar, and a variety of igneous metamorphic and sedimentary clasts and grains. There is a complete gradation of compositions between these end members.

\section{DISCUSSION}

In summary, there are several important points to emphasize about the contourites recovered from the Hatton Drift sites in the Northeast Atlantic.

1. The overall morphology of Hatton Drift, the differential rates and thicknesses of sediment accumulation, and the known present-day hydrographic regime in the area lead us to infer that deposition has been influenced by bottom currents since early Eocene time. However, strong bottom currents at first prevented any significant deposition, and it was only after mid-Miocene time that drift accumulation began.

2. Minor hiatuses and condensed sequences with deepwater authigenic glauconite appear to be indicative of relatively strong bottom currents that, nevertheless, allow some deposition. 
3. In general, the characteristics of these mid-ocean drift contourites are very similar to those of pelagites and hemipelagites. In particular, they are compositionally relatively pure carbonate biogenic oozes, for the most part, with interbeds of more terrigenous material in the upper few tens of meters related to climatic fluctuation. Clearly, the bottom currents have acted simply as agents of (?slight) lateral transport, winnowing, reworking, and deposition of whatever material was introduced into the bottom nepheloid layer from pelagic settling through the overlying water column.

4. The sedimentary characteristic that most clearly indicates bottom current action is the lamination. This is mostly slightly wavy and irregular but generaly parallelsided and with minor bioturbation throughout. It is not ubiquitous, but interbedded with more homogeneous bioturbated sediment and much less evident in the late Pliocene to Recent section. This is perhaps indicative of somewhat reduced bottom currents during, at least, the colder climatic episodes.

5. The Hatton Drift contourites show many of the characteristics summarized by Stow and Lovell (1979) for sandy and muddy contourites and are of the biogenic compositional type described by Stow and Holbrook (1984).

\section{ACKNOWLEDGMENTS}

We thank the secretarial and technical staff of the Grant Institute of Geology for their help. DAVS acknowledges support from the Royal Society of Edinburgh and the Nuffield Science Foundation. Drs. Roger Scrutton and Robert Kidd reviewed an earlier version of the manuscript.

\section{REFERENCES}

Davies, T. D., and Laughton A. S., 1972. Sedimentary processes in the North Atlantic. In Laughton, A. S., Berggren, W. C., et al., Init. Repts. DSDP, 12: Washington (U.S. Govt. Printing Office), 905-934.

Ewing, J. I., Ewing, M., Windisch, C., and Aitken, T., 1974. Underway marine geophysical data in the North Atlantic, Parts E and F: Seismic reflection profiles. In Talwani, M. (Ed.), Lamont-Doherty Survey of the World Ocean.

McCave, I. N., Lonsdale, P. F., Hollister, C. D., and Gardner, W. D., 1980. Sediment transport over the Hatton and Gardar contourite drifts. J. Sediment Petrol., 50:1049-1062.

Rivière, A., 1977. Méthodes granulométriques: Techniques et interprétation: Paris (Masson).

Roberts, D. G., and Montadert, L., 1979. Margin paleoenvironments of the northest Atlantic. In Montadert, L., Roberts, D. G., et al., Init. Repts. DSDP, 48: Washington (U.S. Govt. Printing Office), 1099-1118.

Ruddiman, W. F., 1972. Sediment redistribution on the Reykjanes Ridge: Seismic evidence. Geol. Soc. Am. Bull. 83:2039-2062.

Schnitker, D., 1980. Global paleoceanography and its deep water linkage to the Antarctic glaciation. Earth Sci. Rev., 16:1-20.

Shor, A. W., and Poore, R. Z., 1979. Bottom currents and ice rafting in the North Atlantic: In Luyendyk, B. P., Cann, J. R., et al., Init. Repts. DSDP, 49: Washington (U.S. Govt. Printing Office), 859-872.

Stow, D. A. V., 1982. Bottom currents and contourites in the North Atlantic. Bull. Inst. Geol. Bassin d'Aquitaine, 31:151-166.

Stow, D. A. V., and Holbrook, J. A., 1984. North Atlantic contourites: An overview. In Stow, D. A. V., and Piper, D. J. W. (Eds.), Fine-Grained Sediments: Deep-Water Processes and Facies: Oxford (Blackwells), Geol. Soc. London Spec. Publ., 14:245-256.

Stow, D. A. V., and Lovell, J. P. B., 1979. Contourites: Their recognition in modern and ancient sediments. Earth Sci. Rev., 14:251-291.

Date of Acceptance: December 22, 1983 